Article

\title{
Multiple Dynamic Mechanisms of Globalization: Alternatives to Capitalism
}

\author{
Yu Huang ${ }^{1,2}$, Yuejing $\mathrm{Ge}^{1,3, *}$ and Wei $\mathrm{Hu}^{1}$ \\ 1 Faculty of Geographical Science, Beijing Normal University, Beijing 100875, China; \\ 201631170015@mail.bnu.edu.cn (Y.H.); huweilt1990@163.com (W.H.) \\ 2 Department of Geography, University of California, Los Angeles, CA 90095, USA \\ 3 School of Geographical Science, Qinghai Normal University, Xining 810008, China \\ * Correspondence: geyj@bnu.edu.cn; Tel.: +86-10-5880-2612
}

Received: 9 August 2019; Accepted: 25 September 2019; Published: 27 September 2019

check for updates

\begin{abstract}
As one of the most striking topics in the contemporary world economy, the discussion on globalization seems to take capitalism as the main dynamic mechanism for its practice process, i.e., capital-driven globalization. Although many researchers have proposed other alternative solutions that are crucial to the development of globalization, relevant research is still very insufficient. Based on this point, this study aims to explore the driving forces, action mechanisms, manifestations, and influences of the contemporary globalization process in a more comprehensive way, particularly focusing on the dynamic mechanisms of globalization other than capitalism, and trying to explain the interaction between various dynamic mechanisms. Overall, this paper summarizes three major (but not all) dynamic mechanisms of the contemporary globalization: capital-driven, state-driven, and inter-state cooperation-driven. These three dynamic mechanisms act on different spaces in different ways, exert different influences, and have profound interactive relations on the process of globalization. By showing a more comprehensive picture of globalization, this study attempts to explain the existing alternatives to capital-driven globalization, and encourages a more in-depth discussion of anti-globalization and regional integration as alternative options for globalization from the perspective of internal operation mechanism.
\end{abstract}

Keywords: globalization; dynamic mechanisms; neoliberalism; capitalism; inter-state cooperation

\section{Introduction}

The process of globalization and its impact on the world have become one of the most controversial topics nowadays. Globalization is understood not only as a political and economic term but also as a process of interrelated world development and a controversial political agenda. In general, globalization is seen as a capital-driven process of global interdependence that encourages greater integration of global markets and deregulation. However, in the face of the widening regional development gap, the ongoing global economic crisis, and other challenges of global development and governance, the approach to globalization espoused by western capitalism (especially neoliberalism) is facing increasing skepticism and forcing the world, especially the periphery region and also the inner core of capitalism where the deep structural crisis is severe, to look more urgently for alternatives to globalization. Although most of the existing studies have focused on the globalization of western capitalism, another way of globalization, mainly in emerging economies, (which is known as state capitalism) has also attracted much attention. Besides, there are still some marginal (but important) forms of globalization that deserve further discussions, such as human-based globalization, especially the remittance and investment of transnational labor, and inclusive globalization driven by cooperation between countries initiated by China's Belt and Road initiative (BRI). To some extent, these non-western 
and non-capitalist globalization approaches have become the alternatives to the western capitalist globalization, and are especially important for the countries or regions that are still on the edge of globalization. On the surface, the globalization strategies and characteristics of almost all countries or regions show highly mixed characteristics, and during this process, various actors (governments, enterprises, organizations, individuals, etc.) play different roles in various ways. At the same time, due to the profound interaction among various globalization approaches, there are obvious linkage effects among various factors and strategies in the globalization process. As such, classification research is more convenient and effective in dealing with such complex problems. Through the discussion of classification and interactive relations, we can more clearly understand the causes and effects of various globalization approaches. Through categorical research, this paper focuses on (but is not limited to) the driving forces, action mechanisms, manifestations, and influences of the contemporary globalization process, especially the non-western and non-capitalist globalization process, and the interaction between various dynamic mechanisms of globalization.

Specifically, this paper firstly reviewed the connotation of globalization in the current literature. Based on reviewing the existing literature on the driving forces and development process of globalization, the main part of this paper summarized the three major dynamic mechanisms of the contemporary globalization from the aspects of driving forces, action mechanisms, manifestations, and influences: capital-driven globalization, state-driven globalization, and inter-state cooperation-driven globalization. Then, by focusing on the capital-state relationships and the interaction of various elements in the process of inter-state cooperation-driven globalization, this paper discussed the interaction between different dynamic mechanisms of globalization. Finally, in the conclusion and discussion section, we compared and summarized the influences of these three dynamic mechanisms on different regions of the world, and discussed the shortcomings of this study and future research prospects.

\section{Three Interpretations of Globalization}

Globalization is a process of extension, acceleration, and intensification of economic, political and social interconnections worldwide [1]. The meaning of globalization can be interpreted from at least three aspects: globalization as a process, globalization as a keyword of world politics and economy, and globalization as a political agenda. First of all, as a process, globalization is not a new phenomenon, but an evolving historical process. The process of globalization began in the agricultural civilization era around 9000/11,000 years ago, which called Pre-modern globalization (9000/11,000 years ago-1500). The globalization of this period was manifested in long-distance trade and cross-space power projection among the agricultural civilization centers of Eurasia, Africa, and America. The subsequent stages of globalization include Early Modern globalization (1500-1850), Modern globalization (1850-1945), and Contemporary globalization (1945-) [2]. Other scholars also have different classification methods, for example, Murray is more concerned on the globalization that developed after 1500, and he created a framework to represent the globalization stages and their characteristics. The framework begins with the rise of the Spanish empire in the early 16th century, and then the process of globalization is divided into two waves: Colonial globalization (1500-1945) and Post-colonial globalization (1945-), each wave was further decomposed into two stages. The first wave included the Mercantilist phase (1500-1800) and the Industrialist phase (1800-1945), the second wave consists of the Modernization phase (1945-1980) and the Neoliberal phase (1980-) [3]. Most of these studies, which regard globalization as a development process, are typical historical analyses, emphasizing the historical continuity and staged features of globalization. Second, globalization, as a keyword of world politics and a global economy, first appeared in Merriam Webster's New International Dictionary in 1961, and has increasingly become the focus of debate and concern since the 1990s. This focus on globalization stems from the key changes of industry, finance, and technology which took place in the 1960s and 1970s. These innovations and advances in different fields have contributed to different forms of global interdependence and the collective impact of globalization, such as the influences on finance, trade, migration, communications, media, political organization, 
and even on the spread of new diseases [1]. Therefore, it arouses public concern and made globalization into a hot keyword of world politics and the economy. Finally, globalization as a political agenda refers to the powerful political consequences that began with the popularity of the term "globalization" in the 1980s [4]. The political meaning of the term "globalization" increasingly links national policies to the acceptance that economic growth and development depend on integration with global markets and the freeing of commerce from state control [1]. Put differently, it is the economic globalization of neoliberalism (advocating the governance model of political deregulation), which is driven by the global competition between the United States and the Soviet Union after world war II and the creation of a series of global governance institutions, especially after the oil crisis in 1973 [3]. Therefore, in some people's understanding, the connotation of globalization is often associated with the political influences and reform pressure of this neoliberal globalization.

In general, these three different explanations for globalization shows the complexity of this phenomenon itself. As a process, globalization advocates understanding the space-time process from a distant historical perspective. And as a key term in world politics and economy, globalization emphasizes the process and influences of the contemporary global interdependence. However, globalization as a political agenda derives from the need for expansion of capital-driven globalization (which will be explored in-depth in the next section).

\section{The Three Dynamics of Globalization}

The dynamic mechanisms (or causation) of globalization is one of the key debates in the study of globalization [3]. Most scholars believe that globalization is mainly driven by capitalism [5], while some believe that it is driven by technology [6] or that multiple interlocking factors in the fields of culture, politics, economy, and technology are related. A more detailed study explores the different dynamic characteristics of globalization in different periods. For example, Murray believes that the impetus for Colonial globalization (1500-1945) came from the search for resources and locations for the investment of surplus capital, and the resulting colonialism and other overt political means. In the Modernization phase (1945-1980), globalization was driven by national developmentalism, especially the promotion of transnational corporations. However, after the oil crisis and the debt crisis (Neoliberal stage, after 1980), the power of the state was challenged by global institutions and civil society. The main driving force of globalization came from the spread of capitalist culture, that is, through the development of time-space compression technology to reduce the capital turnover time [3]. Thus, globalization does not have an inevitable trajectory. It is the result of human collective action, agenda, desire, and perception. Under the agency of different actors (generally governments, organizations, companies or individuals, etc.), globalization presents different characteristics through the application of different policy measures and implementation means. It is worth noting that multiple dynamic mechanisms of globalization always work together within a country or region, so that globalization presents a mixed complex appearance and even a tendency of convergence. But the dynamics of globalization are fundamentally different (more on this later). At the same time, due to the different levels of development, history, culture, political system, and other aspects, different parts of the world have different ways to integrate into globalization. In particular, some non-western and non-capitalist modes of globalization have to some extent become the alternative to western capitalist modes of globalization, actively shaping the world's economic pattern and influencing its development trend. But most of the existing studies focus on the globalization process of western capitalist countries, ignoring the process and mode of globalization in other regions. Besides, although previous studies have dealt more or less with all kinds of driving forces (most attention is paid to the globalization process of capitalism), there is a lack of comparison of the principles, forms, and influences of various driving forces, and less attention is paid to the interaction between these driving forces. Because of this, the categorization study offers the possibility of a clearer representation of globalization, which is also the starting point of this paper. In the following section, we explained the principles and influences of various driving forces by classification and comparison with each other and then explain the highly mixed dynamic characteristics of globalization in today's 
world from the perspective of interactive relations. So as to provide a reference for understanding various measures taken by different actors to integrate into globalization. It is also pointed out that the mixed characteristics of different driving forces of globalization can provide more alternatives for the development trend of the globalized world to some extent.

Specifically, according to the characteristics of the cross-border flow of resources in the process of globalization, combined with the purpose and influences of different actors and their initiatives, this paper distinguishes three main (but not all) dynamic mechanisms of globalization (Table 1). Through literature analysis and case study, the principles and characteristics of the three dynamic mechanisms of globalization are discussed qualitatively. Besides, this paper pays particular attention to the comparative analysis of the principles of the three dynamic mechanisms of globalization, their modes of action and influences in different regions of the world, as well as the internal relations of the three dynamic mechanisms.

Table 1. Comparison between the three dynamic mechanisms of globalization.

\begin{tabular}{|c|c|c|c|c|c|}
\hline & Driving Forces & Mechanisms & Manifestations & Influences & Cases \\
\hline Capital-driven & $\begin{array}{l}\text { The principle of } \\
\text { capital } \\
\text { pursuing profit }\end{array}$ & $\begin{array}{l}\text { The global } \\
\text { expansion of } \\
\text { surplus capital } \\
\text { to complete the } \\
\text { process of } \\
\text { capital } \\
\text { circulation }\end{array}$ & $\begin{array}{l}\text { The spread of } \\
\text { privatization, market } \\
\text { economy, competition, } \\
\text { free trade, and western } \\
\text { democracy }\end{array}$ & $\begin{array}{l}\text { The growing } \\
\text { inequality between } \\
\text { the core region and } \\
\text { the periphery } \\
\text { region, and the } \\
\text { deep structural } \\
\text { crisis of capitalism }\end{array}$ & $\begin{array}{c}\text { International } \\
\text { economic } \\
\text { organizations (G7/8, } \\
\text { IMF, WB, WTO) }\end{array}$ \\
\hline State-driven & $\begin{array}{l}\text { Economic } \\
\text { security and } \\
\text { development of } \\
\text { the country }\end{array}$ & $\begin{array}{l}\text { The central role } \\
\text { of the states in } \\
\text { the global } \\
\text { economy }\end{array}$ & $\begin{array}{l}\text { State intervention in } \\
\text { economic activities }\end{array}$ & $\begin{array}{l}\text { Successful } \\
\text { experience for } \\
\text { emerging } \\
\text { economies, but } \\
\text { often combined } \\
\text { with nationalism }\end{array}$ & $\begin{array}{c}\text { The government-led } \\
\text { competitive } \\
\text { export-oriented } \\
\text { economic sector in } \\
\text { South Korea; } \\
\text { Russia's strategic use } \\
\text { of energy as a foreign } \\
\text { policy tool }\end{array}$ \\
\hline $\begin{array}{l}\text { Inter-state } \\
\text { cooperation- } \\
\text { driven }\end{array}$ & $\begin{array}{l}\text { Global } \\
\text { problems and } \\
\text { the resulting } \\
\text { wave of } \\
\text { anti-globalization }\end{array}$ & $\begin{array}{l}\text { Address global } \\
\text { issues through } \\
\text { inter-state } \\
\text { cooperation }\end{array}$ & $\begin{array}{l}\text { The integration of } \\
\text { national development } \\
\text { strategies and } \\
\text { complementarity of } \\
\text { development } \\
\text { advantages and needs } \\
\text { among countries }\end{array}$ & $\begin{array}{l}\text { More balanced and } \\
\text { sustainable } \\
\text { development of } \\
\text { globalization, but } \\
\text { challenged by the } \\
\text { state-centered } \\
\text { thinking mode }\end{array}$ & $\begin{array}{l}\text { The Belt and Road } \\
\text { initiative; Russia's } \\
\text { Eurasian Union }\end{array}$ \\
\hline
\end{tabular}

\subsection{Capital-Driven Globalization}

The first and most influential driving force of globalization is the establishment of a global circuit of capital based on the nature of profit-pursuing [5], which is the process of globalization in a general sense. and we call this form capital-driven globalization. The rise of this globalization process is closely related to the development and expansion of the capitalist economic system [3] and it is considered as the main driving force of the interdependence of global society since the 16th century. In particular, while the inherent economic characteristics of the capitalist led to a growing number of global connections, including through the Internet [1]. Under the influence of Marxism, the process of globalization is interpreted as the global expansion of surplus capital to complete the process of capital circulation. Specifically, it can be divided into three types: the commodity capital circuit is realized through global trade, the currency capital circuit is realized through transnational investment, and the production capital circuit is realized through the global production network and a chain of transnational corporations [3]. Since capital urgently needs to pursue profit maximization in the shortest time (by accelerating the turnaround time of the capital cycle), at the same time, the pressure of competition leads to the need to constantly look for ways to reduce costs and obtain higher profits. These possibilities include the search for global raw materials, labor, and markets, as well as technological means to speed transportation and overcome distance (remove spatial barriers) [1,7], which results in the compression of time-space and the capital-driven globalization [5]. 
The spread of privatization, market economy, competition, free trade, and western democracy are the main characteristics of capital-driven globalization (generally can be summarized as the neoliberalism trend after the Washington consensus). Capitalism is seen as a moral good and it is believed that privatization and market competition (by improving efficiency and quality while reducing cost) not only directly provides consumers with cheaper goods and services, but also indirectly reduces the tax burden [8], and leads to an increase in global well-being [3]. Capital-driven globalization is seen as an inevitable part of modernity, progress, and human evolution, in which citizens and states, for better or worse, will have to learn to participate [3]. The free flow of capital between sectors, regions, and countries are considered essential to the normal and lasting functioning of globalization, so a number of complementary structures emerged, such as the G7/8 Group of advanced capitalist countries [8], the International Monetary Fund (IMF), the World Bank (WB), and the World Trade Organization (WTO) [3]. Since the degree of neoliberalism has become the measure of a good business environment and become the key to determine the success of countries in the competition, it has forced most countries around the world to gradually promote neoliberal reforms [8]. Since 1970, the capital-driven globalization has been widely accepted and practiced all over the world [8], especially strongly supported by the most powerful countries in the global capitalist economy (such as the United States and the United Kingdom) [7], and also reflected in China's reform of the socialist market economy since the Reform and Opening Up (so much so that many western scholars think China has become a capitalist country [9] with Chinese characteristics or a Chinese model that challenges the existing capitalist framework [10], which is called China's new capitalism [11]). A more radical view of capital-driven globalization (the hyper globalists) is that the world economy is borderless, facilitated by circuits of capital, characterized by a single global market operating through transnational networks of production, trade, and finance, and that new global (borderless) elites are created by the forces of market economy [3].

In the capital-driven globalized economic system, the challenge for countries is to compete as effectively as possible in a more integrated and interdependent economic environment, and enterprises are also confronted with worldwide competition and constant restructuring [12]. This liberal and open capital-driven globalization have indeed brought benefits to some countries, but these benefits have been strictly limited geographically [12] and, more seriously, have resulted in the persistence of growing inequality between the core region and the periphery region [3] and between the different classes. The development of capitalism in core areas is likely to weaken the possibility of marginal space to develop in the same way [13]. Every major meeting of the IMF, the World Bank, and the WTO is now a venue for conflict and turmoil [3], while the more general daily resistance to globalization and neoliberalism persists in the lives of many marginalized people [14]. This means that alternatives to capital-driven globalization are necessary for the disadvantaged periphery [13]. At the same time, the deep structural crisis of capitalism also makes the core area face more and more tests, as the rapid growth and equitable income distribution of Fordism have given way to a neoliberal era of secular stagnation, high levels of inequality, instability, and stagnant or declining living standards of the working class. The deterioration of living standards and the failure to bring about a satisfactory improvement in the living standards of the majority [15] are major determinants of the growth of populism and the radical right, and the serious consequence is the rise of populist uprisings represented by Brexit and Trump [16], which are supposed to change the global economic order [17].

In addition to the global flow of capital, the worldwide migration of humans driven by economic factors is also an important impetus of globalization. This human-driven globalization can largely be seen as a variant of capital-driven globalization. However, it is worth noting that in addition to economic consideration, human-driven globalization is more influenced by the factors that lead to individual migration, such as marriage, education, war, disaster, disease, and so on. The driving force of human-driven globalization comes from the practice of individuals relying on the global network of relations, which emphasizes the importance of social network relations based on family, community, ethnic group, religion, and class to the process of globalization. As actor-network theory 
emphasizes [18] that the global economy is made up of social actors engaged in various networks of spatial relationships, the intentional behaviors of actors (driven by individual needs for survival and development) and the relationships among actors in the network are embedded or occur in a specific space, and the interdependency pattern of the world system (namely the process of globalization) is constantly promoted and remolded through the relationship network. According to the characteristics of actors and networks, human-driven globalization can be divided into elite-driven globalization and transnational labor-driven globalization.

The elite-driven globalization includes the global networks established and maintained by the global business elite and the cross-border movement of highly skilled workers. These two elite classes can easily cross national borders with their economic capital, social capital, and cultural capital, construct globally beneficial network relations and factor flows for their development, and thus drive the process of globalization. Specifically, a single global market economy and the resulting global business empire allowed the global business elite to get rid of the control of a single country, seek unprecedented wealth in the global scope, and use vast amounts of social and economic capital to build a global network of connections that sustain and expand their permanent advantages, which includes membership-based restaurants, clubs, and entertainment venues, and even social settings such as conferences and workshops for business elites [19], so as to promote their practice of globalization. Highly skilled workers (doctors, engineers, natural and computer scientists, mathematicians, etc.), by virtue of the transnational flow of its cultural capital, are another component of elite-driven globalization. The large flow of highly skilled workers from developing countries to developed countries (mainly the United States, Canada, Britain, and Australia) [12] further exacerbates the gap in development potential between developed and developing countries. For developing countries, reducing the brain drain and attracting highly skilled workers (typically those who have studied abroad) back to work is also seen in part as key to introducing new technologies and integrating into the global economic system.

The global network of transnational labor is a form of bottom-up globalization that provides fully viable global opportunities for millions of people around the world [19] (despite the relatively small amount of capital involved by individuals) and has played a crucial role in the operation of the global economic system [20]. The globalization practice of transnational labors (including remittance and investment [21] is largely derived from the strong interaction between transnational labors and their domestic family members or their home countries, which transfers funds from the countries where transnational labors are located to their home countries [12], thus promoting the economic growth of the home countries (mainly developing countries). The economic links (mainly through remittances) between transnational labors and their domestic families are not only an important source of income for their families but also the main source of foreign exchange income in many low-income countries, which is more than three times as much as official development assistance [22]. Remittances from transnational labor are so large that international rating agencies give them almost the same credit rating as oil exports [20]. Transnational remittances are seen not only as a major tool for reducing the scale and severity of poverty in developing countries [23] but also as having a positive [24-26] and even crucial [12,27] link with economic growth in developing countries. In addition to transnational remittances, the investment of overseas workers in their home countries is also regarded as a powerful driving force for the economic development of their home countries. For example, about $80 \%$ of China's foreign direct investment comes from Chinese in Southeast Asia [28], which is considered crucial to China's economic development. Other examples can be found from Brazil, El Salvador, Honduras, Jamaica, Peru, Mexico, Panama, and Turkey, which have issued bonds backed by remittances from the United States $[29,30]$ and the Nepalese government (through diaspora bonds) has raised about 100 million dollar in infrastructure funds from Nepalese workers in the Middle East [31]. The remittance and investment of transnational labor, under the background of economic globalization, have narrowed the economic development gap between developed and developing countries to a certain extent. This process is of great significance to rebalance the global economic system, and its influences have 
gone far beyond the regions of their migration countries and home countries and are pushing the reshaping of the global macroeconomic process [32].

The human-driven globalization goes hand in hand to some extent with capital-driven globalization. On the one hand, the process of global capital flow and the regional development differences caused by it become the catalyst of human transnational flow. The worldwide profit-seeking process of capital promotes the transnational flow of individuals. The high-yielding business activities of distant regions and the ambition of capital to conquer global markets strongly attract (or force) individuals to embark on transnational adventures. In this sense, the process of globalization is inseparable from the historical process of worldwide migration and even colonization. Up to the present day, the impact of this capital-seeking process on human mobility is still being felt in multinational business travel (although it has to some extent been replaced by virtual travel brought by information technology), as well as expatriate employees in the overseas branches of multinational companies. But the more remarkable cross-border flows of humans in today's world are essentially the result of the uneven development of the world caused by capital-driven globalization. The strong unbalanced development of the world makes the nationality difference and regional difference brought by the individual's birth become one of the most important factors restricting the individual development [33], and crossing borders has become the most convenient way to seek a better standard of living and change destiny, which has led to the remarkable phenomenon of cross-border labor and immigration in today's world. On the other hand, contrary to capital-driven human flows, the capital still requires individuals to judge and determine its end use or the best way to profit. As the carrier of capital, various behavioral motives of human (non-capital seeking principle) have regulatory effects on the flow of capital. Examples include investment decisions, and remittances and investments by transnational workers to their home countries. Of course, the interdependence between human and capital also shows strong inequality, this interdependence of inequality is strongly reflected in the difference between the poor, capital-driven labors and the capital players who run the show. Although the relationship between personal development and capital profit-seeking is very close, there is still tension and conflict between them. Specifically, to some extent, the profit-seeking capital can help some individuals obtain their development needs, but in other cases, capital gains are based on depriving other people's development opportunities, which leads to the unstable relationship between individual development and profit-seeking capital. That is part of the reason why neoliberalism is in crisis.

\subsection{State-Driven Globalization}

Another form of globalization is state-driven globalization, which emphasizes the central role of the state in global economic construction and regulation [3]. State-driven globalization is based on the premise that the state is the main actor in the global economy. There are at least four important reasons for this premise. Firstly, the current territory is more fixed than in the past, so the role of the government in national affairs is greater than ever before [3]. Secondly, globalization is regarded as an agenda advocated by developed capitalist countries [4], which aims at opening up new capital opportunity space [34] for developed capitalist countries (mainly G8) on a global scale to realize their global interests [35]. Thirdly, the different approaches adopted by other countries (which are also involved in globalization) to integrate into the dominant capitalist [12] world economic system are all trying their best to improve their competitive position in the world economy [12]. Fourthly and finally, the limitations of liberal economic theory [36] and the failure of neoliberal models in many countries have led to the rise of the "state-social-market" complex development model in some emerging economies since the 1990s. The most important commonality of this mode is that the state occupies an important position in market economic activities, which is also known as state capitalism [37,38]. This practice of state-driven globalization is part of the global wave of "depoliticization" since the end of the cold war [39], which aims to make the national economy better and faster integrating into the world capitalist system, and to achieve more rapid national capital accumulation and expansion [38]. 
The state is generally recognized as a major actor in the global economy. Influenced by neoliberalism (advocating the free market and free trade), developed capitalist countries strongly advocate the restriction of state intervention, but in practice, there are always various interventions, such as the steel tariffs in the United States and the agricultural protections in Europe [8]. But the more radical process of state-driven globalization mainly occurs in the countries that are marginalized in the international system and have the goal of catching up and rapidly industrializing [40]. The will of the state is used to guide economic development in line with the political and economic development direction of the country and society [41]. At the same time, with the development of external markets and new capital instruments, the state can achieve more effective control over the decline of direct economic involvement [42]. These new capital instruments include the national Oil and Gas Corporations, other state-owned enterprises, privately owned national champions, sovereign wealth funds, and state-owned banks [43]. Specific practices of state-directed economic development include intelligence sharing between state institutions and private enterprises, successful economic diplomacy [36], and so on. Since the mid-1990s, in some emerging economies, state-driven globalization has allowed the governments to strengthen their control over the commanding heights of the national economy while the private sector grows [44]. At the same time, these countries have greatly promoted the globalization of enterprises (transnational corporations) [3], and as the agents of the country's transnational economic activities, the transnational corporations are still deeply rooted in the national territory $[12,45]$.

State-driven globalization is an important principle and successful experience for the development of emerging economies. For example, by developing a (government-led) competitive export-oriented economic sector, South Korea has grown from a fairly poor country (in the 1960s) to a developed and prosperous one in just 30 years [37]. Other examples include Singapore and several other developing countries in Asia, which have both encouraged competition and embraced free trade rules while actively intervening in building infrastructure to foster a good business environment, and this combination creates opportunities for the countries and elevates their standing in international competition [8]. Different from the neoliberal pursuit of short-term economic interests [46], state-driven globalization pays more attention to the importance of national economic security and long-term and strategic benefits in the increasingly fierce competition, and is more inclined to use economic means to achieve strategic objectives, such as Russia's strategic use of energy as a foreign policy tool [36]. However, it is worth noting that the process of state-driven globalization is often combined with nationalism, which also became a lasting feature of the global economy. For example, the anti-immigrant sentiment in Europe and the rise of ethnic nationalism after the economic collapse of Indonesia resulted in brutal attacks on the local ethnic Chinese minorities, and nationalist sentiment is similarly high in South Korea and Japan [8]. In addition, the repression of the state-driven economic development model of emerging economies by western developed countries [47] is also thought-provoking. In the neoliberal market economy system of western countries, the practice of state-driven globalization in many emerging economies has been accused by Western countries of using state-owned enterprises to manipulate markets, posing major risks to global investment activities, and causing imbalances in global economic development [48]. Therefore, some Western developed countries try to suppress the economic development of emerging economies in order to maintain the development advantages of Western countries.

\subsection{Inter-State Cooperation-Driven Globalization}

With the implementation of the Belt and Road initiative (BRI) led by China, the process of globalization driven by inter-state cooperation (i.e., new globalization, also known as inclusive globalization [49] has become a new agenda in the process of globalization. The driving force of inter-state cooperation-driven globalization comes from the three major global problems of insufficient global growth momentum, lagging global governance system, and imbalanced global development [50] caused by the defects of neoliberal globalization, and the resulting wave of anti-globalization $[51,52]$. 
In order to solve the three major problems of global development and enable more regions to share the benefits of globalization [49], with the implementation of the BRI, China has embarked on a new path of globalization, namely, to provide the new driving force for the global economy through cooperation between countries.

To be specific, first of all, inter-state cooperation-driven globalization emphasizes that states, as the main actors of globalization, should respect each other's independent choice of development path $[49,53]$. In particular, it emphasizes that poor and weak countries should regain the dominant power of their development under the impact of neoliberal "de-nationalization" [51,54]. Secondly, inter-state cooperation-driven globalization emphasizes the role of the national government in economic development (rather than relying on market mechanisms to solve all problems) [55]. On the one hand, effective government regulation [49] can be adapted to make up for the shortage of long-term investment (such as various infrastructure projects with large and long investment cycles, includes roads, railways, and ports [56], safety risks, hot money flooding, and other inherent shortcomings of the market mechanism [57]), so as to guide the rational flow and efficient allocation of capital, technology, talents, and other elements [54] (the most notable manifestation is the flow of capital towards infrastructure and real economy [58]). On the other hand, it emphasizes the role of the government in maintaining social equity and reducing poverty [53] and pays more attention to environmental sustainability and the improvement of governance capacity [49]. Third, in contrast with the current competitive logic of globalization [59], the inter-state cooperation-driven globalization emphasizes considering the joint relationship between common development and universal security among countries. That is, it advocates that the governments of all countries should go beyond national interests and think about their symbiotic relationship with other countries from a global perspective [54], to strike a balance between independent development and integrated development. To be specific, this globalization approach advocates seeking the convergence of interests and the common development through the docking of development strategies between countries $[53,60]$. Fourth, unlike the unbalanced global development caused by the principle of capital pursuing profit, the globalization driven by cooperation among countries aims to solve the problems of unbalanced global development by focusing on countries and regions with a relatively backward development level (these regions are less likely to make profits). It also avoids the mercenary nature of transnational capital and actively responds to the appeal of people of all countries for a better life. Through interconnected development among countries, inter-state cooperation-driven globalization is committed to benefiting all relevant countries, regions, and people [61], thus enhancing the moral character of global development [54].

Globalization driven by inter-state cooperation emphasizes the important role of inter-state cooperation in global development. At the macro level, globalization driven by cooperation among countries advocates the integration of national development strategies. Examples of this model include China's BRI, "Juncker plan" in the European Union, Russia's "Eurasian Union", the "Northern Powerhouse" of England, Pakistan Vision 2025, Mongolia Steppe Road Program, Kazakhstan "Bright Road" Initiative, Turkey's "Middle Corridor", the Amber Road Initiative of Poland, etc. In particular, inter-state cooperation-driven globalization is based on the complementarity of development advantages and needs among countries. It involves making use of the capital, technology, and other advantages of developed countries, and starting from the investment related to industrialization, urbanization, and other infrastructure to promote the less developed countries to industrialize centering on infrastructure construction and the manufacturing industry [55]. At the same time, cross-border cooperation should be used to improve inter-state connectivity in the fields of transportation, finance, energy, information, and culture [62]. In the end, it will encourage the less developed countries to integrate into the global economy and share the fruits of development, thus driving the economic development and consumption capacity growth of the less developed regions, invigorating the global economic cycle [63] and benefiting the less developed countries and developed countries in general. The mode of inter-state cooperation-driven globalization is still at the initial stage, but the reshaping of the globalization pattern under the guidance of its goal can be seen in two aspects. 
First, compared with the traditional way of globalization, the globalization driven by cooperation between countries lays more emphasis on the construction of the interconnection of the marginal areas [58], which will promote the marginal areas to change the blocking and backward development pattern [63]. Second, inter-state cooperation-driven globalization emphasizes solving the problems of unbalanced global development and the development gap between countries and the social income gap by reducing the economic backwardness of underdeveloped regions [54]. However, it is worth mentioning that there are also many different opinions on the potential impact of such cooperation between countries led by one or several countries. Despite Chinese official denials, many scholars have interpreted the BRI from a geopolitical perspective [64-66], focus on the geopolitical interpretation behind large connectivity projects [67], which emphasizes that the initiative is seeking to strengthen China's dominant position, and the inevitability of accepting it as a geopolitical initiative, especially for countries other than China [68]. This kind of state-centered thinking mode also reflects the great challenges faced by inter-state cooperation-driven globalization.

\section{The Interaction among the Dynamic Mechanisms of Globalization}

Although their mechanisms of action and spatial influences are quite different, the three main dynamic mechanisms of globalization still have a profound interaction in the global interdependent system, and jointly affect the intricate process of globalization. One of the most noteworthy interactions is the coordination between capital-driven globalization and state-driven globalization. Overall, more and more countries are defining themselves as partners of capital. On the one hand, the globalization of capital and the world market have become the main ways for countries to expand their influences (which can be summarized as geoeconomy), so as to shape and manage the strategic environment for a country to pursue its national interests through economic means [69]. Economic competition is displacing, though not completely displacing, the territorial animosity of the world's most developed regions [70], so much so that with the advent of globalization, the discussion of empires is once again in vogue [71]. The most representative is that the United States, out of consideration for its national interests and ideology [71], uses its state machinery to eliminate the blank areas of globalization in the world. As a result of this, the war against terrorism around the world by the United States was to a large extent interpreted as a war to complete the geoeconomic globalization of the American empire [71]. On the other hand, the fundamental task of capital-driven globalization is to create conditions for the accumulation of highly profitable capital, which reflects the interests of private property owners, enterprises, transnational corporations, and financial capital [8]. These interest groups work closely with the states, playing a strong (mainly self-interested) role in approving laws, deciding on public policies, and setting up rules and regulations [8], and operate through the agency of the state's foreign, military, and commercial policies [7]. At the domestic level, state power is often used to aid companies financially or to transfer financial failures, and to crush opponents when necessary. In the United States, for example, incarceration has become a key government strategy for dealing with laid-off workers and marginalized groups [8]. At the international level, the International Monetary Fund and the World Bank are given the power (by core neoliberal states) to coordinate debt relief (often with added requirements for lower living standards and structural adjustment in third world countries). These international institutions, through regulation and intervention, transfer wealth from poor countries to rich countries (known as Predatory Accumulation) [8], while using state monopolies on violence and definitions of legitimacy to avoid general collapse and popular unrest [8]. Through close cooperation between the state and capital, various interests and power relations in the process of globalization are adjusted. As a result, this kind of cooperative relationship continuously strengthens the operation ability of capital and shapes the power of the transnational bourgeoisie, while state power shows a very unbalanced trend of change, as some countries retain or even expand their power, while others lose their power [71].

The process of inter-state cooperation-driven globalization is influenced by the interaction among the states, capital, and individuals, and it also affects the global flow of capital and humans. Inter-state 
cooperation-driven globalization is trying to break the imbalance of international development caused by capital accumulation. In essence, based on state-driven globalization, the inter-state cooperation-driven globalization establishes state-to-state cooperative relations by coordinating the development modes of different countries, to seek common development among countries. Therefore, its characteristics can be summarized as a cooperative geoeconomy. The process of inter-state cooperation-driven globalization is largely driven by state developmentalism and led by the government, which relies on the national strong ability to allocate transnational economic resources (including the cross-border flow of capital and people, as well as the strong financing and investment capacity of the government). However, in the process of its implementation, it also attaches great importance to giving full play to the autonomy of enterprises (as the main body of implementation) while being guided by the state and combining the benefits of enterprises with the social and political benefits of the state. However, as the process of inter-state cooperation-driven globalization is still in the initial stage, the further observation and research of the combination mechanism of multiple agents and the interaction between different dynamic mechanisms are still needed.

\section{Conclusions and Discussion}

Capital-driven globalization is about seeking profits for capital on a global scale. As the most important dynamic mechanism of globalization, capital-driven globalization has been widely applied in the world. However, it is mainly developed countries and the bourgeoisie that continuously concentrate their development advantages through the capital cycle and thus continuously aggravate the global unbalanced development. State-driven globalization seeks to use the developmental advantages of a country in the world economic system. Although all countries in the world have a certain degree of state-centered developmentalism, state-driven globalization mainly promotes the rapid development of emerging economies. But at the same time, the globalization process driven by the state, because of its strong government role, can easily lead to the speculation of geopolitical games, and then lead to the risk of global political competition. These two dynamic mechanisms of globalization are the strategic choices of capital, humans, and countries for seeking their development under the logic of economic competition. In contrast, inter-state cooperation-driven globalization emphasizes the importance of abandoning competition and seeking cooperation among countries, aiming to seek common development paths for different countries from the perspective of global development, so as to cope with the severe challenges of governance deficit, trust deficit, and development deficit in today's world [72]. By comparing these three different dynamic mechanisms of globalization, this study explains various existing alternatives to the capital-driven globalization in today's world. These dynamic mechanisms of globalization focus on different regions, different scales, and different ways to play their roles, respectively. At the same time, different dynamic mechanisms also have a profound interactive impact on each other, jointly promoting the deepening of global interdependence.

Different countries, regions, and individuals integrate into globalization in various ways. At the same time, for a particular country or region, multiple dynamic mechanisms of globalization also work together, and there is almost no complete capital-driven or state-driven globalization. For example, the Chinese economy is characterized by significant government intervention [11], but we must also acknowledge the central role that decentralization and reduction of central government control over economic activity have played in driving China's recent growth $[9,73]$. Nor can we deny the important role of the American government in participating in economic activities and containing capitalist crises through the establishment and administration of the juridical, regulatory, and infrastructural framework in which private property, competition, and contracts came to operate [74]. However, by distinguishing different dynamic mechanisms of globalization, it is possible to understand the root causes behind various measures taken by countries, regions, and individuals in pursuit of a more advantageous position in globalization more clearly, and how these highly mixed dynamic mechanisms of globalization exhibit more diverse characteristics to meet the challenges of globalization. It is closely related to the stability and sustainable development of the global economic system for different actors 
to seek the best way and maintain the balance between the dynamic mechanisms of globalization so that all participants can enjoy the benefits of globalization more equitably. Further discussions about globalization will focus on how to find a sustainable development path between the infinite growth needs of the economy and the limited ecological capacity of the earth. It is expected that the globalization driven by cooperation between countries will inevitably respond to these challenges.

And beyond the phenomenon of globalization itself, anti-globalization and regional integration are also phenomena that cannot be ignored in today's world economy. To some extent, they have become alternatives to globalization. The phenomenon of anti-globalization is caused by the negative effects in the process of globalization, such as various riots caused by the ever-increasing development imbalance related to the capital-driven globalization, and the national trade protectionism caused by the excessive use of nationalism in the state-driven globalization. To some extent, the phenomenon of regional integration is very similar to the inter-state cooperation-driven globalization mentioned in this paper, as they both emphasize the importance of transnational cooperation for national development, but there are some more obvious differences to note: first, regional integration emphasizes cooperation among countries adjacent to each other in space, which is exclusive to other countries and different from the inclusiveness emphasized by inter-state cooperation-driven globalization. Second, the actor of regional integration is changed from states to a regional organization under this model. The states carry out regional cooperation by transferring part of their sovereignty, which is different from the state sovereignty emphasized by the globalization driven by inter-state cooperation. However, on the whole, anti-globalization, regional integration, and globalization have interlocked influences to jointly shape the world economic system. Therefore, more in-depth studies should focus on the discussion of the more intricate mechanisms behind these different phenomena and their changing trends.

Author Contributions: Y.H. played an important role in original draft, project administration, and performed the methodology and formal analyses. Y.G. contributed to the conceptualization of the study, played a vital role in supervision and funding acquisition. W.H. made an important contribution in review, editing, and validation.

Acknowledgments: This work is supported by the National Natural Science Foundation of China (Grants No. 41871128), the major project of National Social Science Foundation of China (Grants No. 16ZDA041), and the China Scholarship Council. All the authors gratefully thank the reviewers and editors for their insightful and constructive comments.

Conflicts of Interest: The authors declare no conflict of interest.

\section{References}

1. Sparke, M. Introducing Globalization: Ties, Tensions, and Uneven Integration; John Wiley \& Sons: Hoboken, NJ, USA, 2013.

2. Held, D.; McGrew, A.; Goldblatt, D.; Perraton, J. Global Transformations: Politics, Economics and Culture; Polity Press: Cambridge, UK, 1999.

3. Murray, W.E.; Overton, J. Geographies of Globalization; Routledge: New York, NY, USA, 2015.

4. Firth, S. The Pacific Islands and the globalization agenda. Contemp. Pac. 2000, 12, 177-192. [CrossRef]

5. Harvey, D. The Condition of Postmodernity: An Enquiry into the Origins of Cultural Change; Blackwell: Oxford, UK, 1990.

6. Ohmae, K. The End of the Nation State; Free Press: New York, NY, USA, 1995.

7. Harvey, D. Spaces of Hope; University of California Press: Berkeley/Los Angeles, CA, USA, 2000.

8. Harvey, D. A Brief History of Neoliberalism; Oxford University Press: Oxford, UK; New York, NY, USA, 2007.

9. Nee, V.; Opper, S. Capitalism from Below: Markets and Institutional Change in China; Harvard University Press: Cambridge, MA, USA, 2012.

10. Peck, J.; Zhang, J. A variety of capitalism ... with Chinese characteristics? J. Econ. Geogr. 2013, 13, 357-396. [CrossRef]

11. Ten Brink, T. China's Capitalism: A Paradoxical Route to Economic Prosperity; University of Pennsylvania Press: Philadelphia, PA, USA, 2019.

12. Knox, P.; Agnew, J.; Mccarthy, L. The Geography of the World Economy; Routledge: New York, NY, USA, 2014. 
13. Sheppard, E. Limits to Globalization: The Disruptive Geographies of Capitalist Development; Oxford University Press: Oxford, UK, 2016.

14. Routledge, P. Resisting and reshaping destructive development: Social movements and globalizing networks. In Geographies of Global Change: Remapping the World, 2nd ed.; Johnston, R.J., Taylor, P.J., Watts, M., Eds.; Blackwell: Oxford, UK, 2002.

15. Baccaro, L. Remarks Given at the Panel "New Approaches to Political Economy"; Society for the Advancement of Socio-Economics: Kyoto, Japan, 2018.

16. Kinderman, D.P. The Neoliberal Revolution in Industrial Relations. Catal. A J. Theory Strategy 2019, 2, 106-124. [CrossRef]

17. Habib, J.; Howard, M. The Political Economy of Donald, J. Trump. In Reading Donald Trump; Palgrave Macmillan: Cham, Switzerland, 2019; pp. 103-125.

18. Dicken, P.; Kelly, P.F.; Olds, K.; Wai-Chung Yeung, H. Chains and networks, territories and scales: Towards a relational framework for analysing the global economy. Glob. Netw. 2001, 1, 89-112. [CrossRef]

19. Thrift, N.; Tickell, A.; Woolgar, S.; Rupp, W. Globalization in Practice; Oxford University Press: Oxford, UK, 2014.

20. Zapata, G.P. The migration-development nexus: Rendering migrants as transnational financial subjects through housing. Geoforum 2013, 47, 93-102. [CrossRef]

21. Samet, K. Circular migration between the North and the South: Effects on the source Southern economies. Procedia-Soc. Behav. Sci. 2013, 93, 2234-2250. [CrossRef]

22. World Bank. Migration and remittances: Recent Developments and Outlook. In Migration and Remittance Brief 30; World Bank: Washington, DC, USA, 2018.

23. Ratha, D. The impact of remittances on economic growth and poverty reduction. Policy Briefs 2013, 8, 1-13.

24. Lim, S.; Simmons, W.O. Do remittances promote economic growth in the Caribbean Community and Common Market? J. Econ. Bus. 2015, 77, 42-59. [CrossRef]

25. Feeny, S.; Iamsiraroj, S.; McGillivray, M. Remittances and economic growth: Larger impacts in smaller countries? J. Dev. Stud. 2014, 50, 1055-1066. [CrossRef]

26. Kumar, R.R. Remittances and economic growth: A study of Guyana. Econ. Syst. 2013, 37, 462-472. [CrossRef]

27. Martinez, C.; Cummings, M.E.; Vaaler, P.M. Economic informality and the venture funding impact of migrant remittances to developing countries. J. Bus. Ventur. 2015, 30, 526-545. [CrossRef]

28. Callahan, W. China: The Pessoptimist Nation; Oxford University Press: Oxford, UK; New York, NY, USA, 2010.

29. Ratha, D. Workers' remittances: An important and stable source of external development finance. Econ. Semin. Ser. 2003, 9, 157-175.

30. Ratha, D. US Signs Historic Deal with El Salvador and Honduras for Remittance Securitization. People Move: A Blog about Migration, Remittances, and Development; World Bank: Washington, DC, USA, 2010.

31. Ratha, D. Whatever Happened to Nepal's Diaspora Bonds? People Move: A Blog about Migration, Remittances, and Development; World Bank: Washington, DC, USA, 2010.

32. Guarnizo, L.E. The Economics of Transnational Living. Int. Migr. Rev. 2003, 37, 666-699. [CrossRef]

33. Milanovic, B. The haves and the have Nots: A Brief and Idiosyncratic History of Global Inequality; Basic Books: New York, NY, USA, 2010.

34. Hirst, P. From Statism to Pluralism: Democracy, Civil Society and Global Politics; University College London: London, UK, 1997.

35. Gilpin, R.; Gilpin, J.M. Global Political Economy: Understanding the International Economic Order; Princeton University Press: Princeton, NJ, USA, 2001.

36. Csurgai, G. The increasing importance of geoeconomics in power rivalries in the twenty-first century. Geopolitics 2018, 23, 38-46. [CrossRef]

37. Chung, Y.I. South Korea in the Fast Lane: Economic Development and Capital Formation; Oxford University Press: Oxford, UK, 2007.

38. Zhang, X. Emerging economies are catching up, state capitalism and the world order. J. East China Norm. Univ. 2015, 4, 66-74.

39. Wang, H. Depoliticized Politics: The End of the Short 20th Century and the 1990s; SDX Joint Publishing Company: Beijing, China, 2008.

40. Duvall, R.D.; Freeman, J.R. The state and dependent capitalism. Int. Stud. Q. 1981, 25, 99-118. [CrossRef] 
41. Wang, F. Definition of socialist market economy with Chinese characteristics—Based on the criticism of "new state capitalism". J. Manag. 2015, 6, 15-23.

42. Zhang, X. The Belt and Road in the rise of state capitalism. Beijing Cult. Rev. 2015, 3, 30-35.

43. Bremmer, I. The End of the Free Market: Who Wins the War between States and Corporations; Portfolio: New York, NY, USA, 2010.

44. The Economist. Special Report: State Capitalism; The Economist: London, UK, 2012.

45. Allen, J.; Thompson, G. Think global, then think again-Economic globalization in context. Area 1997, 29, 213-227. [CrossRef]

46. Yan, H. China in Africa, and criticized Harvey's Western Center. 2015. Available online: http://www.shiwuzq. com/portal.php? $\bmod =$ view\&aid=168 (accessed on 6 May 2015).

47. Liu, X. Investor protection of state-owned enterprises under "state capitalism"-From the perspective of investment treaty innovation. Law Sci. 2018, 5, 15-27.

48. The, U.S.-China Economic and Security Review Commission. 2016 Annual Report to Congress. Available online: https://www.uscc.gov/Annual_Reports/2016-annual-report-congress (accessed on 16 November 2016).

49. Liu, W.; Dunford, M.; Gao, B. A discursive construction of the Belt and Road Initiative: From neo-liberal to inclusive globalization. J. Geogr. Sci. 2018, 28, 1199-1214. [CrossRef]

50. People.cn. Share the Responsibility of The Times and Promote Global Development. Available online: http://theory.people.com.cn/n1/2018/0104/c416126-29746002.html (accessed on 17 January 2017).

51. Wei, L. The Belt and Road: Engine of new globalizaiton. J. Lanzhou Univ. Soc. Sci. 2017, 45, $23-29$.

52. Gu, S.; Wu, Q.; Wang, J. Research on new globalization and the Belt and Road international cooperation. Study Int. Financ. 2017, 8, 24-32.

53. Liu, W. Inclusive Globalization: New Philosophy of China's Belt and Road Initiative. Bull. Chin. Acad. Sci. 2017, 32, 331-339.

54. Zhang, W. The Belt and Road: The exploration and practice of the new globalization. Contemp. World 2018, 3 , $56-59$.

55. Zhong, F. The Belt and Road, new globalization and great power relations. Foreign Aff. Rev. 2017, 34, 1-26.

56. National Development and Reform Commission. Vision and Actions on Jointly Building Silk Road Economic Belt and 21st-Century Maritime Silk Road. 2015. Available online: http://en.ndrc.gov.cn/newsrelease/201503/ t20150330_669367.html (accessed on 28 March 2015).

57. Wang, Y. The Belt and Road: Creating a new civilization of inclusive globalization. Sci. Technol. China 2017, 11, 38-40.

58. Wang, Y. How the Belt and Road reshapes globalization. Belt Road Rep.. 2018, 3, 12.

59. Sun, Q.; Suo, L.; Zheng, W. “The Belt and Road” and new type of globalization: Risks and solutions. J. Party Sch. Cent. Comm. C.P.C. 2017, 21, 100-106.

60. Tang, X.; Zhang, H. The Belt and Road: China's solution in the era of globalization and transformation-A review of the 120th session of the Boya forum at Peking University. Econ. Sci. 2018, 3, 14-20.

61. Hu, B.; Liu, Q.; Sun, Y.; Wang, S.; Sun, B. The Belt and Road and global transformation. Rev. Econ. Res. 2017, 55, 3-4.

62. Task Group of China International Economic Exchange Center. The "belt and road" Initiative creates a win-win new realm of the development of economic globalization. Globalization 2017, 7, 20-38.

63. Gu, Q. The Belt and Road will Lead to a New Type of Globalisation. Available online: http://intl.cssn.cn/gj/ gj_gwshkx/gj_zhyj/201805/t20180502_4220609.shtml (accessed on 2 May 2018).

64. Blanchard, J.M.F. Probing China's Twenty-First-Century Maritime Silk Road Initiative (MSRI): An Examination of MSRI Narratives. Geopolitics 2017, 22, 246-268. [CrossRef]

65. Brewster, D. Silk roads and strings of pearls: The strategic geography of China's new pathways in the Indian Ocean. Geopolitics 2017, 22, 269-291. [CrossRef]

66. Sidaway, J.D.; Woon, C.Y. Chinese narratives on "One Belt, One Road" in geopolitical and imperial contexts. Prof. Geogr. 2017, 69, 591-603. [CrossRef]

67. Blanchard JM, F.; Flint, C. The geopolitics of China's maritime silk road initiative. Geopolitics 2017, 22, $223-245$. [CrossRef]

68. Palit, A. India's economic and strategic perceptions of China's maritime silk road initiative. Geopolitics 2017, 22, 292-309. [CrossRef] 
69. Vihma, A. Geoeconomic analysis and the limits of critical geopolitics: A new engagement with Edward Luttwak. Geopolitics 2018, 23, 1-21. [CrossRef]

70. Moisio, S. From enmity to rivalry? Notes on national identity politics in competition states. Scott. Geogr. J. 2008, 124, 78-95. [CrossRef]

71. Smith, N. American Empire: Roosevelt's Geographer and the Prelude to Globalization; University of California Press: Berkeley/Los Angeles, CA, USA, 2003.

72. Xinhua News. Wangyi: The Three Deficits in the World Today. Available online: http://www.xinhuanet.com/ world/2018-06/04/c_1122935818.htm (accessed on 6 June 2018).

73. Lin, Y.M. Between Politics and Markets: Firms, Competition, and Institutional Change in Post-Mao China; Cambridge University Press: Cambridge, UK, 2001; Volume 18.

74. Gindin, S.; Panitch, L. The Making of Global Capitalism; Verso Books: Brooklyn, NY, USA, 2012; p. 3.

(C) 2019 by the authors. Licensee MDPI, Basel, Switzerland. This article is an open access article distributed under the terms and conditions of the Creative Commons Attribution (CC BY) license (http://creativecommons.org/licenses/by/4.0/). 